\title{
Thermodynamic and potentiometric investigation of the surface processes on $\mathrm{Hg}_{3} \mathrm{In}_{2} \mathrm{Te}_{6}$ electrodes
}

\author{
Oxana SEMA ${ }^{1}$, Volodymyr DIICHUK ${ }^{1}$, Igor KOBASA ${ }^{1 *}$ \\ ${ }^{1}$ Department of Chemical Analysis, Food Safety and Testing, Yuriy Fedkovych Chernivtsi National University, \\ Kotsyubynskoho St. 2, 58012 Chernivtsi, Ukraine \\ * Corresponding author.Tel: +380-372-584897; e-mail: i.kobasa@chnu.edu.ua
}

Received October 10, 2016; accepted December 28, 2016; available on-line August 14, 2017

The influence of chemical etching and preliminary cathodic and anodic polarization on the stationary electrode potential of a $\mathrm{Hg}_{3} \mathrm{In}_{2} \mathrm{Te}_{6}$ electrode has been investigated in various acidic solutions with different pH-values. It is shown that $\mathrm{In}^{3+}$ ions govern the process of formation of a double electric layer at the interphase semiconductor/electrolyte for electrodes submitted to preliminary chemical etching and anodization, while $\mathrm{Hg}^{2+}$ ions play the leading role in a similar process occurring on the electrodes after cathodic polarization.

$\mathrm{Hg}_{3} \mathrm{In}_{2} \mathrm{Te}_{6}$ / Pourbaix diagram / Thermodynamic analysis / Cathodic and anodic polarization

\section{Introduction}

The physicochemical processes taking place at the semiconductor/electrolyte interphase are the basis for many technological stages of surface treatment required for the production of semiconducting materials with tailored electrophysical properties. Among others, porization, oxidation and sulfidizing of the surface by various chemical and electrochemical methods can be mentioned as the operations used most widely. These operations attract extensive attention because they can ensure the formation of a nanostructured surface of both elementary semiconductors and complex semiconducting compounds. In this context, monocrystalline $\mathrm{Hg}_{3} \mathrm{In}_{2} \mathrm{Te}_{6}$ seems very promising since its electric, optical, magnetic, and some other properties can ensure an efficient utilization of this compound in the production of light-sensitive elements [1], lightabsorption filters [2], ionizing radiation and IR detectors [3-5], and many other devices. However, many aspects related to possible redox processes taking place on the electrode surface are still unknown, and the chemical and electrochemical stability ranges of this electrode are also undefined.

Consequently it seemed of interest to investigate the parameters of the reactions running at the interphase $\mathrm{Hg}_{3} \mathrm{In}_{2} \mathrm{Te}_{6}$ /electrolyte since these processes govern the chemical dissolution of the surface and formation of oxide films.

\section{Experimental}

Monocrystalline $\mathrm{Hg}_{3} \mathrm{In}_{2} \mathrm{Te}_{6}$ samples with n-type conductivity obtained by the Bridgman method were used throughout this investigation. A film of gold was deposited on the back side of a $\mathrm{Hg}_{3} \mathrm{In}_{2} \mathrm{Te}_{6}$ electrode according to [6] and then the copper wire was soldered to the film to ensure electric contact with the electrode. The contact spot and unused areas of the electrode were isolated by picein. All the electrodes were chemically etched in a polishing solution (5\% $\mathrm{Br}_{2}$ in $\mathrm{CH}_{3} \mathrm{OH}$ ) and then thoroughly rinsed by bidistillate water prior to every measurement.

Electrochemical measurements were carried out in $\mathrm{HCl}-\mathrm{NaCl}$ solutions using a $\mathrm{pH}$-meter to study the influence of the composition of the system on the $\mathrm{pH}$-value. Monocrystalline semiconducting plates were used in the potentiometric investigations. The potential of the electrode was measured against a silver chloride electrode according to [7] with an accuracy of $\pm 2 \mathrm{mV}$.

\section{Results and discussion}

A comprehensive investigation of the interphase $\mathrm{Hg}_{3} \mathrm{In}_{2} \mathrm{Te}_{6} /$ electrolyte was performed in $[7,8]$ using a thermodynamic approach based on the construction of Pourbaix diagrams. This approach makes it possible to predict which electrochemical processes will take 
place on the electrode surface, and which products will be formed as a result. The Pourbaix diagram for the system $\mathrm{Hg}_{3} \mathrm{In}_{2} \mathrm{Te}_{6}-\mathrm{H}_{2} \mathrm{O}$ [7] is shown in Fig. 1.

The range of existence of the solid phase $\mathrm{Hg}_{3} \mathrm{In}_{2} \mathrm{Te}_{6}$ in aqueous solutions can be obtained from the analysis of the diagram $\mathrm{pH}$ - redox potential. The upper boundary of the range is indicated by the broken line extending between the potentials -0.459 and $-1.227 \mathrm{~V}$. The character of the electrode reactions in each part of this line depends on the $\mathrm{pH}$, the redox potential of the system, and the activity of the potential-determining ions. If the media is strongly acidic $(\mathrm{pH}<3)$, ionization of the components that enable stoichiometric dissolution of $\mathrm{Hg}_{3} \mathrm{In}_{2} \mathrm{Te}_{6}$ prevails. As the $\mathrm{pH}$-value shifts towards alkaline, surface oxidation of the electrode can start and passivating films of $\mathrm{TeO}_{2}, \mathrm{HgO}, \mathrm{Hg}(\mathrm{OH})_{2}$, and $\mathrm{In}(\mathrm{OH})_{3}$ will appear on the surface of the semiconductor. When the $\mathrm{pH}$ reaches neutral and weak alkaline values, tellurium will leave the passivating film and form $\mathrm{HTeO}_{3}^{-}$and $\mathrm{TeO}_{3}{ }^{-}$ions. Furthermore, dissolution of $\operatorname{In}(\mathrm{OH})_{3}$ and formation of
$\mathrm{InO}_{2}^{-}$become theoretically possible when $\mathrm{pH}$ reaches strongly alkaline values $(\mathrm{pH}>13)$.

The chemical composition and structure of the surface of the semiconductors have a great influence on the electrochemical properties. They can be changed by chemical etching, preliminary cathodic polarization (cathodic reduction of the surface), and anodic polarization (anodic oxidation of the semiconductor surface). For this reason the influence of the surface pretreatment on the standard electrode potential has also been studied in this work.

Two parts related to the above methods of preliminary surface treatment can be identified in the $E=\mathrm{f}(\mathrm{pH})$ curves (Fig. 2). The first part corresponds to strongly acidic solutions and shows a decrease in the electrode potential with increasing $\mathrm{pH}$. The second part corresponds to weakly acidic systems and the electrode potential slightly rises with increasing $\mathrm{pH}$ within this part. The position of the change of slope of the line depends on the surface pretreatment regime. For chemical etching of the electrodes after cathodic reduction, the discontinuity will be at $\mathrm{pH}=4.2$ while in the case of anodic oxidation it will be at $\mathrm{pH}=3.3$.

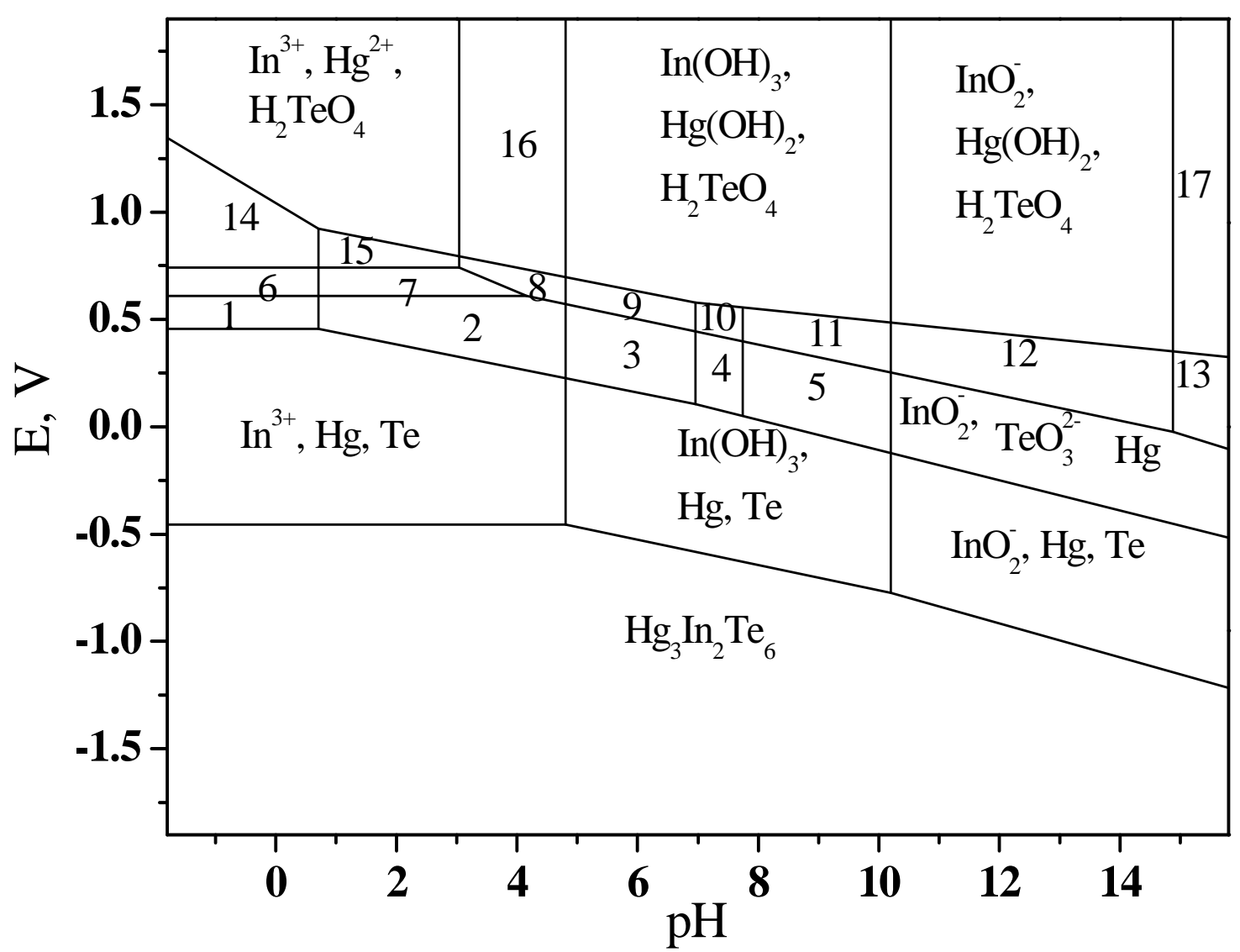

Fig. 1 Pourbaix diagram for the system $\mathrm{Hg}_{3} \mathrm{In}_{2} \mathrm{Te}_{6}-\mathrm{H}_{2} \mathrm{O}\left(\mathrm{C}=10^{-6}\right.$ mole/l $)$ :

Regions: $1-\mathrm{In}^{3+}, \mathrm{Hg}, \mathrm{Te}^{4+} ; 2-\mathrm{In}^{3+}, \mathrm{Hg}, \mathrm{TeO}_{2} ; 3-\mathrm{In}(\mathrm{OH})_{3}, \mathrm{Hg}, \mathrm{TeO}_{2} ; 4-\mathrm{In}(\mathrm{OH})_{3}, \mathrm{Hg}^{3}, \mathrm{HTeO}_{3}{ }^{-}$; $5-\mathrm{In}(\mathrm{OH})_{3}, \mathrm{Hg}, \mathrm{TeO}_{3}{ }^{2-} ; 6-\mathrm{Hg}_{2}{ }^{2+}, \mathrm{In}^{3+}, \mathrm{Te}^{4+} ; 7-\mathrm{Hg}_{2}{ }^{2+}, \mathrm{In}^{3+}, \mathrm{TeO}_{2} ; 8-\mathrm{Hg}(\mathrm{OH})_{2}, \mathrm{In}^{3+}, \mathrm{TeO}_{2} ; 9-\mathrm{Hg}(\mathrm{OH})_{2}$, $\mathrm{In}(\mathrm{OH})_{3}, \mathrm{TeO}_{2} ; 10-\mathrm{Hg}(\mathrm{OH})_{2}, \mathrm{In}(\mathrm{OH})_{3}, \mathrm{HTeO}_{3}^{-} ; 11-\mathrm{Hg}(\mathrm{OH})_{2}, \mathrm{In}(\mathrm{OH})_{3}, \mathrm{TeO}_{3}{ }^{2-} ; 12-\mathrm{Hg}(\mathrm{OH})_{2}, \mathrm{InO}_{2}^{-}$, $\mathrm{TeO}_{3}{ }^{2-} ; 13-\mathrm{HHgO}_{2}^{-}, \mathrm{InO}_{2}^{-}, \mathrm{TeO}_{3}{ }^{2-} ; 14-\mathrm{Hg}^{2+}, \mathrm{In}^{3+}, \mathrm{Te}^{4+} ; 15-\mathrm{Hg}^{2+}, \mathrm{In}^{3+}, \mathrm{TeO}_{2} ; 16-\mathrm{In}^{3+}, \mathrm{Hg}(\mathrm{OH})_{2}$, $\mathrm{H}_{2} \mathrm{TeO}_{4} ; 17-\mathrm{HHgO}_{2}^{-}, \mathrm{InO}_{2}^{-}, \mathrm{H}_{2} \mathrm{TeO}_{4}$. 


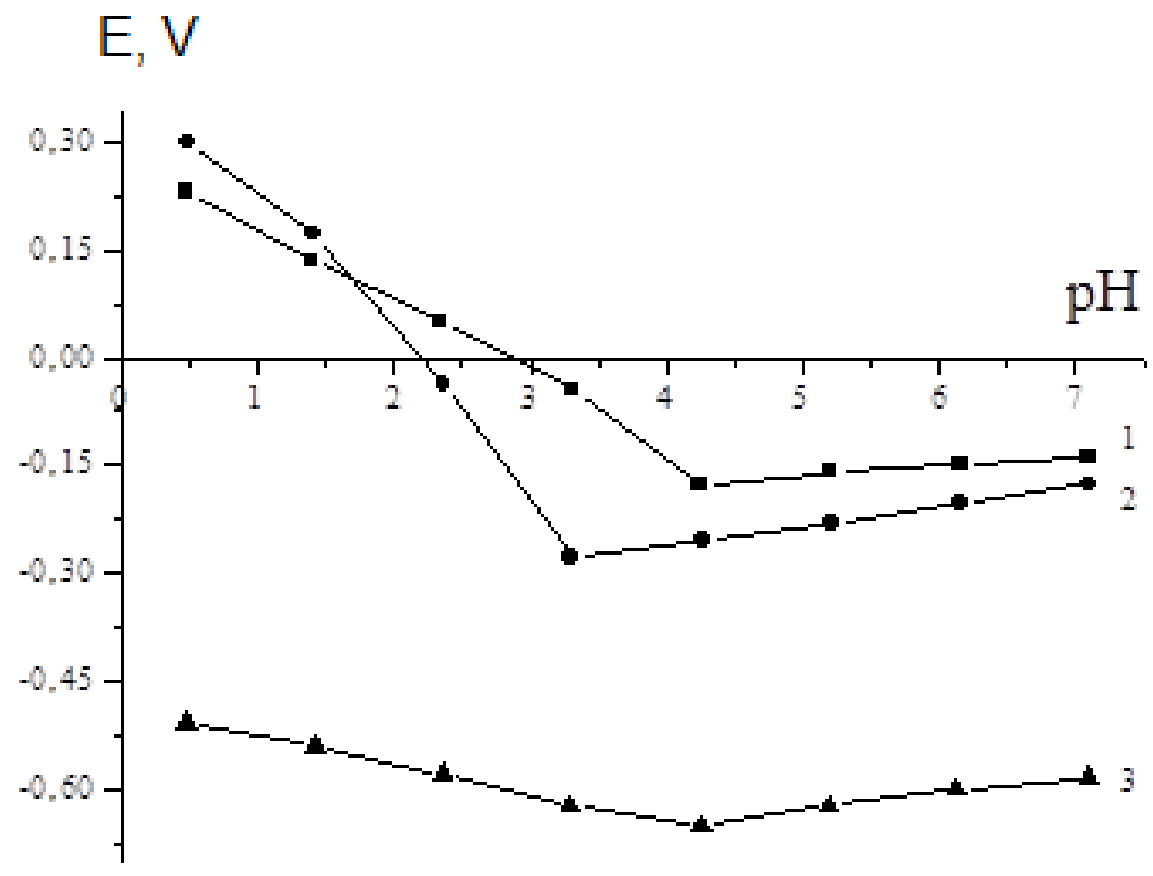

Fig. 2 Dependence of the stationary potential of $\mathrm{Hg}_{3} \mathrm{In}_{2} \mathrm{Te}_{6}$ on $\mathrm{pH}$ in the system $\mathrm{HCl}-\mathrm{NaCl}$.

1 - chemically etched electrode surface; 2 - anodically oxidized electrode surface; 3 - cathodically reduced surface.

Table 1 Influence of the $\mathrm{Hg}_{3} \mathrm{In}_{2} \mathrm{Te}_{6}$ surface pretreatment regime on the linear regression coefficients of $E=\mathrm{f}(\mathrm{pH})$.

\begin{tabular}{l|c|c|c}
\hline \multicolumn{1}{c|}{ Pretreatment regime } & \multirow{2}{*}{$\mathrm{pH}$ range } & \multicolumn{2}{c}{ Coefficients } \\
\cline { 3 - 4 } & & $E^{0}, \mathrm{~V}$ & $\mathrm{~d} E / \mathrm{d}(\mathrm{pH}), \mathrm{V}$ \\
\hline Chemical etching & $1.0 \div 4.2$ & 0.362 & -0.136 \\
& $4.2 \div 7.0$ & -0.255 & 0.014 \\
\hline Same as above + anodic polarization in $0.1 \mathrm{~N} \mathrm{NaCl}$ at & $1.0 \div 3.3$ & 0.445 & -0.188 \\
$U_{\mathrm{C}}=+1.0 \mathrm{~V}, \tau=15$ min & $3.3 \div 7.0$ & -0.235 & 0.014 \\
\hline Same as above + cathodic polarization in $0.1 \mathrm{~N} \mathrm{NaCl}$ at & $1.0 \div 4.2$ & -0.440 & -0.301 \\
$U_{\mathrm{A}}=-1.0 \mathrm{~V}, \tau=15$ min & $4.2 \div 7.0$ & -0.752 & 0.024 \\
\hline
\end{tabular}

The pretreatment regime influences also the slope coefficients $(\mathrm{d} E / \mathrm{d}(\mathrm{pH}))$ of the lines. This can be caused by switching between different electrode reactions that become the potential-determining process at the same $\mathrm{pH}$-value [9]. A similar situation has also been observed for polarized $\mathrm{Hg}_{3} \mathrm{In}_{2} \mathrm{Te}_{6}$ electrodes.

The coefficients have been calculated (see Table 1) for the linear parts of the experimental lines shown in Fig. 2.

As can be seen from the data in Table 1, the first parts of all lines can be characterized by 'hyperNernst' coefficients irrespective of the electrode pretreatment regime used. This is a well-known fact from semiconductor electrochemistry [10], which is related to the simultaneous occurrence of several redox reactions at the semiconductor/electrolyte interphase.
The second parts of the lines are characterized by coefficients that are close to the theoretical (Nernst) values: $0.0197 \mathrm{~V} / \mathrm{pH}$ for three-electron and $0.0295 \mathrm{~V} / \mathrm{pH}$ for two-electron elementary redox interactions (see Table 1). Therefore it can be assumed that $\mathrm{In}^{3+}$ ions play a leading role in the formation of a double electric layer in the case of $\mathrm{Hg}_{3} \mathrm{In}_{2} \mathrm{Te}_{6}$ electrodes that have undergone chemical etching and preliminary anodization, while $\mathrm{Hg}^{2+}$ ions govern this process in the case of electrodes after preliminary cathodic polarization.

The reactions that are thermodynamically allowed in the systems $\mathrm{Hg}-\mathrm{H}_{2} \mathrm{O}, \mathrm{In}-\mathrm{H}_{2} \mathrm{O}$, and $\mathrm{Te}-\mathrm{H}_{2} \mathrm{O}$, and the corresponding coefficients of the dependencies $E=\mathrm{f}(\mathrm{pH})$, are presented in Table 2. Some conclusions concerning the potential-determining reactions in the system $\mathrm{Hg}_{3} \mathrm{In}_{2} \mathrm{Te}_{6}$-electrolyte can be drawn based on a comparison of the data in Tables 1 and 2. 
Table 2 Thermodynamically allowed reactions in the systems $\mathrm{Hg}-\mathrm{H}_{2} \mathrm{O}, \mathrm{In}-\mathrm{H}_{2} \mathrm{O}, \mathrm{Te}-\mathrm{H}_{2} \mathrm{O}$ and values of the coefficients in $E=\mathrm{f}(\mathrm{pH})$.

\begin{tabular}{|c|c|c|c|}
\hline No. & Reaction & $E_{298}^{0}, \mathrm{~V}$ & $\mathrm{~d} E / \mathrm{d}(\mathrm{pH}), \mathrm{V}$ \\
\hline 1. & \multicolumn{3}{|c|}{ System $\mathrm{Hg}-\mathrm{H}_{2} \mathrm{O}$} \\
\hline 1.1 & $\mathrm{Hg}_{2} \mathrm{O}+\mathrm{H}_{2} \mathrm{O}+2 \mathrm{e}^{-}=2 \mathrm{Hg}+2 \mathrm{OH}^{-}$ & +0.123 & 0.0591 \\
\hline 1.2 & $\mathrm{Hg}^{2+}+2 \mathrm{e}^{-}=2 \mathrm{Hg}$ & +0.8534 & 0.0295 \\
\hline 1.3 & $\mathrm{HgO}+2 \mathrm{H}^{+}+2 \mathrm{e}^{-}=\mathrm{Hg}^{+}+\mathrm{H}_{2} \mathrm{O}$ & +0.9256 & 0.0591 \\
\hline 1.4 & $\mathrm{HgO}+\mathrm{H}_{2} \mathrm{O}+2 \mathrm{e}^{-}=\mathrm{Hg}+2 \mathrm{OH}^{-}$ & +0.0977 & 0.0591 \\
\hline 1.5 & $\mathrm{Hg}(\mathrm{OH})_{2}+2 \mathrm{H}^{+}+2 \mathrm{e}^{-}=\mathrm{Hg}+2 \mathrm{H}_{2} \mathrm{O}$ & +1.034 & 0.0591 \\
\hline 2. & \multicolumn{3}{|c|}{$\underline{\text { System In }-\mathrm{H}_{2}} \underline{\mathrm{O}}$} \\
\hline 2.1 & $\mathrm{In}^{+}+\mathrm{e}^{-}=\mathrm{In}$ & -0.126 & 0.0591 \\
\hline 2.2 & $\mathrm{In}^{3+}+3 \mathrm{e}^{-}=\mathrm{In}$ & -0.338 & 0.0197 \\
\hline 2.3 & $\mathrm{In}(\mathrm{OH})_{3}+3 \mathrm{H}^{+}+3 \mathrm{e}^{-}=\mathrm{In}+3 \mathrm{H}_{2} \mathrm{O}$ & -0.172 & 0.0591 \\
\hline 2.4 & $\mathrm{InO}_{2}^{-}+4 \mathrm{H}^{+}+3 \mathrm{e}^{-}=\mathrm{In}+2 \mathrm{H}_{2} \mathrm{O}$ & +0.146 & 0.0787 \\
\hline 3. & \multicolumn{3}{|c|}{$\underline{\text { System Te }-\mathrm{H}_{2} \underline{\mathrm{O}}}$} \\
\hline 3.1 & $\mathrm{Te}+2 \mathrm{e}^{-}=\mathrm{Te}^{2-}$ & -1.143 & 0.0295 \\
\hline 3.2 & $2 \mathrm{Te}+2 \mathrm{e}^{-}=\mathrm{Te}_{2}{ }^{2-}$ & -0.840 & 0.0591 \\
\hline 3.3 & $\mathrm{Te}^{2+}+2 \mathrm{e}^{-}=\mathrm{Te}$ & +0.400 & 0.0295 \\
\hline 3.4 & $\mathrm{Te}^{4+}+4 \mathrm{e}^{-}=\mathrm{Te}$ & +0.568 & 0.0147 \\
\hline 3.5 & $\mathrm{TeO}_{2}+4 \mathrm{H}^{+}+4 \mathrm{e}^{-}=\mathrm{Te}+2 \mathrm{H}_{2} \mathrm{O}$ & +0.604 & 0.0591 \\
\hline 3.6 & $\mathrm{H}_{2} \mathrm{TeO}_{3}+4 \mathrm{H}^{+}+4 \mathrm{e}^{-}=\mathrm{Te}+3 \mathrm{H}_{2} \mathrm{O}$ & +0.589 & 0.0591 \\
\hline 3.7 & $\mathrm{TeOOH}^{+}+3 \mathrm{H}^{+}+4 \mathrm{e}^{-}=\mathrm{Te}+2 \mathrm{H}_{2} \mathrm{O}$ & +0.559 & 0.0442 \\
\hline 3.8 & $\mathrm{HTeO}_{3}^{-}+5 \mathrm{H}^{+}+4 \mathrm{e}^{-}=\mathrm{Te}+3 \mathrm{H}_{2} \mathrm{O}$ & +0.713 & 0.0737 \\
\hline 3.9 & $\mathrm{TeO}_{3}^{2-}+6 \mathrm{H}^{+}+4 \mathrm{e}^{-}=\mathrm{Te}+3 \mathrm{H}_{2} \mathrm{O}$ & +0.827 & 0.0885 \\
\hline 3.10 & $\mathrm{Te}+2 \mathrm{H}^{+}=\mathrm{H}_{2} \mathrm{Te}-2 \mathrm{e}^{-}$ & -0.739 & 0.0591 \\
\hline 3.11 & $\mathrm{Te}+\mathrm{H}_{2} \mathrm{O}=\mathrm{HTe}^{-}+\mathrm{OH}^{-}+2 \mathrm{e}^{-}$ & -0.817 & 0.0295 \\
\hline
\end{tabular}

The reactions that most likely take place on the chemically etched electrodes at $\mathrm{pH}$-values ranging from 1 to 4.2 should include tellurium (for instance, reaction 3.3 in Table 2). Oxidation of the semiconductor, which involves a three-electron stage, becomes dominant if the $\mathrm{pH}$ is between 4.2 and 7.0. As seen in Table 2, this can be the reaction 2.2. The ionization of tellurium (reactions $3.3,3.4$ ) can govern the electrode potential at $\mathrm{pH}<3.3$ for anodically oxidized $\mathrm{Hg}_{3} \mathrm{In}_{2} \mathrm{Te}_{6}$ electrodes. Finally, the ionization of surface indium (process 2.2) can be the potentialdetermining reaction in strongly acidic solutions $(\mathrm{pH}<4.2)$ for electrodes that have undergone preliminary cathodic polarization.

Cathodic reduction of tellurium to oxidation state -2 (reactions 3.10 and 3.11; Table 2) are possible in acidic and neutral solutions under cathodic polarization. The oxidation reactions involving surface atoms of mercury and tellurium are the most probable processes for the anodic polarization of $\mathrm{Hg}_{3} \mathrm{In}_{2} \mathrm{Te}_{6}$ in strongly acidic solutions (see processes 1.1, 3.5, 3.6, and 3.7). Anodic polarization in weakly acidic or neutral systems initiates processes involving surface indium atoms (reactions 2.2, 2.3).
It can be concluded that the results of this investigation prove that the redox processes in the system $\mathrm{Hg}_{3} \mathrm{In}_{2} \mathrm{Te}_{6}-\mathrm{HCl}-\mathrm{NaCl}$ are governed by the $\mathrm{pH}$, the redox potential of the system, and the activity of the potential-determining ions. The conditions required for obtaining semiconducting materials with pre-defined electrophysical properties can be found using both potentiometry and thermodynamic analysis.

\section{References}

[1] Y. Li, Fu Li, J. Sun, X. Wang, J. Appl. Phys. 117 (2015) 085704 (6 p.).

[2] O.G. Grushka, A.I. Savchuk, S.M. Chupyra, O.M. Mysliuk, S.V. Bilichuk, V.V. Shlemkevych, Semiconductors 48 (2014) 1271-1274.

[3] V.M. Koshkin, I.N. Volovichev, Yu.G. Gurevich, L.P. Galchinetskyi, I.M. Rarenko. Materials and Equipment with a Giant Radiation Resource, Dielectrics and Conductors into Radiation Detectors, Kharkiv, Institute of Single Crystals, 2006, pp. 5-64. (in Russian) 
O. Sema et al., Thermodynamic and potentiometric investigation of the surface processes on $\mathrm{Hg}_{3} \mathrm{In}_{2} \mathrm{Te}_{6}$ electrodes

[4] M.L. Kovalchuk, M.G. Kolisnyk, O.V. Kopach, V.N. Bazalyuk, Fiz. Khim. Tverd. Tila 9 (2008) 716-722.

[5] O.L. Maslyanchuk, L.A. Kosyachenko, I.I. German, I.M. Rarenko, V.A. Gnatyuk, Phys. Status Solidi C 6 (2009) 1154-1157.

[6] Solution for gilding semiconductors. USSR Authorship certificate 820250, A.G. Voloschuk, Ya.S. Mazurkevych, I.M. Rarenko; Claimed 10.12.79; Published 05.12.80, No. 53.
[7] V.V. Diichuk, A.G. Voloschuk, Nauk. Visn. Chernivtsi Univ., Khim. 606 (2012) 38-42.

[8] O.V. Sema, Nauk. Visn. Chernivtsi Univ., Khim. 771 (2016) 51-55.

[9] G.M. Mokrousov, O.N. Zarubina, Nauchn. Vestn. Tomsk. Politekhn. Inst. 3 (2008) 25-30.

[10] V.A. Batenkov, Electrochemistry of Semiconductors, Barnaul, Altai Univ., 2002, 162 p. (in Russian) 